\title{
Violation on State Sovereignty by Military and Paramilitary Activities on Nicaragua vs United States Case
}

\author{
Nina Zainab ${ }^{1 *}$, Dewa Nyoman Agung Noviardi ${ }^{1}$ and Fadilla Farhan Eka Buana ZK ${ }^{1}$ \\ ${ }^{1}$ Bhayangkara Jakarta Raya University, Bekasi, Indonesia
}

\begin{abstract}
The Sovereignty of the State provides the rights of protection responsibility for the sovereignty of its people, respecting and fulfilling its citizens' rights and cooperate on the international community. However, in certain dispute, the Sovereignty of the State was violated by the internal member of the state, particularly by a military and paramilitary member on the case of Nicaragua vs. the United States. This study examines the use of force by military and paramilitary members as a mean of self-defense. The use of force has violated the state sovereignty and international law on the relation of both countries. The study was conducted by researching relevant decisions and facts of International Law, customary international law, general principles of law, international treaties, conventions, declarations and decisions of international organizations. By using the study materials, in the end, it can be seen how the concept of Sovereignty of the State in International Law.
\end{abstract}

\section{Introduction and Literature Review}

State sovereignty is a very interesting and intensely debated concept in academic discourse in the field of law and international politics. From time to time it can be noted a very dynamic discussion about the concept of state sovereignty in international law. The meaning of the sovereignty of the State in the context of the latest International Law system itself highly regarded as the most controversial one, especially when it is associated with the phenomenon of military members who provide threats and violence to other countries [1].

Virtually, the threat of military violence against a State according to international law occurs when a State takes action - actions that can threaten and violate peace and committing an act of aggression against other States [2].

In accordance with the provisions of the UN Charter and the principle of International Law which states that every State in international relations is prohibited from threatening or acting on military violence against the territorial integrity or national independence of a State, or in any way contrary to the objectives of the United Nations [2].

On the Nicaragua Case, United States has violated Nicaragua's sovereignty, the territorial integrity, and political independence by committing a "covert" war against Nicaragua which resulted in a violation of the most fundamental and universally accepted principles of

\footnotetext{
*Corresponding author: ninazanin@yahoo.com
} 
international law [3]. The violation was made by several allegations: first, mining of Nicaraguan harbors; second, attacking oil installations; third, exerting various forms of economic pressure on Nicaragua and fourth, supporting armed bands of Nicaraguan rebels opposed to the existing Sandinista government [4].

The dispute was settled before the International Court of Justice, where the court found the United States had violated several tenets of customary international law by its activities in and against Nicaragua. However, United States notably argues their acts were committed under the general international legal theory of "collective self-defense", specifically by overthrow Sandinista regime of Nicaragua through Nicaraguan harbors and territory in an effort to subvert the existing government of El Salvador [4].

ICJ also found Nicaragua was engaged in an armed attack against its neighbors, carried out not only by supporting armed groups engaged in military and paramilitary activities in and against El Salvador (and affecting Costa Rica, Honduras and Guatemala as well), but also by direct armed attacks across its border into Honduras and Costa Rica [5]. Thus, the United States argued that under a nation's inherent right of collective self-defense, Nicaragua's conduct permitted the United States to undertake "necessary actions" to support El Salvador [4].

\subsection{Case Overview}

The discordances began in July 1979 when the present Nicaraguan government, the Frente Sandinista de Liberacion Nacional (FSCN) overthrew President Anastasio Somoza Debayle. This change in the government, along with the suspicion of the Soviet Union supports on the Sandinistas, raised fears that the close diplomatic and economic ties the United States enjoyed with countries in Central America were in jeopardy [4].

In 1981, the US had suspended aid because it claimed that the Nicaragua "democratic coalition government" was supporting guerrillas in El Salvador. Two main armed opposition groups, the Fuerza Democratica Nicaraguense (FDN) and Alianza Revolucionaria Democratica (ARDE), developed operating within Honduras and Costa Rica with the alleged covert support of the US [6].

Nicaragua filed an application on April 9, 1984, for proceedings against the US citing their support for military and paramilitary activities in and against Nicaragua. These included armed attacks against Nicaragua, incursions into territorial waters, aerial trespass, indirect and direct means to coerce the Nicaraguan government, operations involved in mining Nicaraguan ports, attacks on ports, oil installations, and naval bases. Additionally, Nicaragua requested a reward of $370,200,000$ to cover damages, including killings of Nicaragua nationals, resulting from violations of international law [6].

On its judgments, the Court rejected the justification of collective self-defense advanced by the United States and stated that it had violated the obligations imposed by customary international law not to intervene in the affairs of another State. The Court also found that the United States had violated certain obligations arising from a bilateral Treaty of Friendship, Commerce, and Navigation of 1956 and that it must make reparation for all injury caused. The amount of that reparation was to be fixed in subsequent proceedings. In March 1988, the United States maintained its refusal to take part in the case. In September 1991, Nicaragua informed the Court that it did not wish to continue the proceedings. The case was removed from the Court's List [7].

\subsection{State Sovereignty on International Law}

A. W. Heffter first speaks of the territorial principle (ius territorii), as grants a "right to integrity or inviolability of states". It entered into the practice of states the United Nations 
(UN) Charter stated the protection of territorial integrity specifically mentioned as a crucial component of the prohibition of the use of force as provided for in Article 2 (4): "All Members shall refrain in their international relations from the threat or use of force against the territorial integrity or political independence of any state, or in any other manner inconsistent with the Purposes of the United Nations" [8].

The founder of sovereignty concept, Bodin established a concept of the sovereignty acts as "a supreme, absolute and independent of the state's laws power over his subjects, which is, however, limited by divine and natural law" [9]. Max Huber on a judgment of the case Island of Palmas, also draw a contemporary definition "[s]overeignty in the relations between states means independence. Independence in relation to an area of the globe is the right to exercise his functions within the state, excluding any other State" [9]. In the Corfu Channel case, sovereignty is defined as a set of rights and attributes possessed by the State in its territory excluding any other State, and also in his relations with other states [9].

The modern approach of state sovereignty in International Law considers state sovereignty and equality as a recognized concept and the basis for the operation of the International Law system. International law generally recognizes that the state as an independent and sovereign entity means that the country is not subject to other higher authorities [2].

Sovereignty and equality of the state are attributes that are inherent in an independent state as a subject of international law. Recognition of state sovereignty and equality between countries is also the basis for state personality in the international legal system [1].

Sovereignty underlies several rights recognized by international law, for example; the right of equality, territorial jurisdiction, the right to determine nationality for the population in its territory, the right to allow and refuse or prohibit people from entering and leaving their territory, and the right to nationalize [1].

\section{Objective of the study}

The purpose of this study is looking for violation of fundamental principles of State Sovereignty by underlying principles of "collective self-defense" committed by the United States on Case Concerning Military and Paramilitary Activities in and against Nicaragua (Nicaragua v. United States of America). Furthermore, the discussion on how sovereignty on International Law should set will also be made.

\section{Methodology}

This study will utilize literature research as the primary methodology. The research will emphasize on 1986 ICJ Judgment as the underlying source, along with customary international law, general principles of law, international treaties, conventions, declarations and decisions of international organizations. The authors will first determine the violation of United Stated simultaneously with the breaching of the Treaty of Friendship, Commerce, and Navigation of 1956. After the violation has been found, the customary international law and the general principles of law will be used as a tool to attributing them with state sovereignty. Experts writing then will be used to resolve the outline of sovereignty on International Law.

\section{Discussion}

Prior to the main discussion on this review, the authors should clarify preliminary issue of jurisdiction arises in the case. The issue of United States contention on how its 1946 declaration of consent to the compulsory jurisdiction of the ICJ would not apply to disputes 
with any Central American state has been settled by ICJ on the first stages of the proceeding. ICJ declared that the application was admissible and that the Court had jurisdiction to hear the case. Article 36 (2) of the ICJ Statute enabled the Court to invoke its compulsory jurisdiction over a state. The first proceeding also emphasized Article 36 (5) of the Statute which asserted declaration of consent to the Permanent Court of International Justice (PCIJ), the predecessor of the ICJ, applicable to the ICJ. In addition, ICJ also determined the effect of an attempt to modify a declaration of consent and discussed the possible additional basis of jurisdiction by virtue of a 1956 Treaty of Friendship [10-11] Furthermore, no additional discussion on jurisdiction would address in this writing.

\subsection{Use of Force}

First and foremost violation of United States towards Nicaragua was the vast military and financial support given by the US between 1981 and 1984 [12]. Those actions were conducted by military and civilian personnel in the official service of the United States, for which the United States is accountable for. As the operations were set along with the line of duty and under the direction of their superiors constitute, under the law, the actions of the United States, the violation then considered as the acts and omissions of all state organs or agents on use of force violation that attributable to the United State [3].

The prohibition of using the force in Article 2 (4) of the United Nation Convention bind all states to its mandate. This then explains furthermore by the International Court of Justice as a peremptory norm of international law, from which states are not lawfully entitled to derogate [13]. As Henderson explain on her review the use of force clause punctuate two proposition: 'First, the use of the word 'force' as opposed to 'war' covers violent situations which do not conform to the technical requirements of the state of war. Secondly, article 2 (4) covers 'threat or use of force', which, it is suggested, has a restrictive effect on the limited exceptions to article 2 (4)" [13]. Moreover, International Law Commission's Commentary to Article 50 of its draft Articles on the Law of Treaties giving the prohibition on the use of force as a rule of jus cogens [14] and therefore provide this principle a non-derogation status under any circumstances.

The judgment of the International Court of Justice along with the writings of jurists, the actions of the United Nations and the positions taken by the United States itself has exhibited the use of force contained in Article 2(4) [3].

\subsection{Violation of State Sovereignty}

The 1970 Declaration on Principles of International Law concerning Friendly Relations and Cooperation among States in accordance with the Charter of the United Nations has emphasized the duty of non-intervention as a correlative of every State's 'inalienable right to choose its political, economic, social and cultural systems [15]. The rights has also given state rights to rule their territorial political community under their legitimate government without foreign intervention, in order to respect the right to self-determination [15].

ICJ elaborated this declaration on their judgment and stated "would make nonsense of the fundamental principle of State sovereignty, on which the whole of international law rests, and the freedom of choice of the political, social, economic and cultural system of a State"[6]. This given unquestionable sovereignty to Nicaragua on how they could address their internal political situation without any intervention from United States.

Furthermore, ICJ in its legal verdict concluded the United States action by the use of force was "in breach of its legal obligations under customary international law not to use force against another state", "not to intervene in its affairs", "not to violate its sovereignty", "not to interrupt peaceful maritime commerce", and "in breach of its obligations under Article 
XIX of the Treaty of Friendship, Commerce and Navigation between the Parties signed at Managua on 21 January 1956" [6].

\subsection{Right of Collective Self Defense}

The doctrine of collective self-defense which used by United States to justify its action lay in Article 51 of the United Nations Charter, which preserves the right to use force in selfdefense "if an armed attack occurs", until the Council has taken the necessary measures.

Further justification also occurred from the Organization of American States (OAS) Charter which United States considered as a Latin American states effort to repel any communist or communist-support. [4] This view also strengthened by The Inter-American Treaty of Reciprocal Assistance which states that when an armed attack occurs within the region, each member may "determine the immediate measures which it may individually take to meet the attack."' Further: "[i]n situations where an American state is threatened by an act of aggression other than an armed attack, an outside conflict, or "any other act or situation" endangering the peace of the hemisphere, the Organ is also to meet without delay to agree on measures to assist the victim of aggression or maintain the security of the continent. "[4]

However, this doctrine is not a free-from-interpretation or unconditional principle. The ICJ judgment has confirmed that it is a well-established rule of customary international law that a use of force in self-defense must be "proportional to the armed attack and necessary to respond to it." [16] The rule of proportionality requires that "the level of force used is not greater than that necessary to end the attack or remove the threat as such it is another way of looking at the requirement of necessity." [16] Another provision for this doctrine is principles of necessity, where the state has to determine the force used was necessary to achieve legitimate ends of self-defense [17].

The requirement of proportionality and necessity was taking into account by ICJ on its judgment on this case. ICJ addressed even tough Nicaragua had used unlawful force by supporting El Salvador rebels, but Nicaragua was not shown to be responsible for providing weapons and supplies to Salvadorian rebels, and further that even if it had done so, the supply of weapons was not the same as an armed attack. [18] The United States action can not justified since the right of self-defense is "limited to the right to use force to repel an attack in progress to prevent future enemy attacks following an initial attack, or to reverse the consequences of an enemy attack, such as ending an occupation" [18] which United States was not in that instance, and was not invited by both El Salvador and Nicaragua in the first place to interfere with their internal politics situation.

United States has failed to conform to the principle of necessity because this required state to restrict the use of military force to the attainment of legitimate military objectives, and the principle of proportionality since United State did not weigh in the possible civilian casualties [18]. Hence United States use of force should consider as an unlawful measure based on International Law principle [6].

\section{Conclusion}

United States action sparks new debate on how to use collective state defense in foreign state internal situation. Despite the United States virtual motivation in helping fellow American country, United States action was not desired in the first place by the disputed party. Moreover, on the action of its collective self-defense, United States does not put the principle of proportionality and principle of necessity into account, whereas those two principles are core requirement on the mentioned action. This move was considered as interfering another states rights to govern their internal political situation. Obviously, United States has violated 
Nicaragua's sovereignty by mining of Nicaraguan harbors attacking oil installations; exerting various forms of economic pressure on Nicaragua and supporting Nicaraguan rebels.

\section{References}

1. S. Riyanto, Yustisia, 1, 3, Pp. 5-14 (2012)

2. S. Suryokusumo, jkn, 8, 1, Pp. 71-76 (2003)

3. C. T. Bernheim, yjil 11, 1, Pp. 104-138 (1985)

4. Z. Modabber, ILR 10, 2, Pp. 449-468 (1988)

5. A. D’Amato, AJIL 79, 3, Pp. 657-664 (1985)

6. Military and Paramilitary Activities in and against Nicaragua (Nicaragua v United States), ICJ, Jurisdiction and Admissibility, Judgment of 26 November 1984

7. The Hague Justice Portal

8. C. Marxsen, HJIL 75, Pp. 7-26 (2015)

9. K. Gevorgyan, Concept of State Sovereignty: Modern Attitudes (YSU Press, Yerevan, 2014)|

10. T. J. Pax, iclr 8, 2, Pp. 471-515 (1985)

11. N. M. Tama, psilr 4, 1, Pp. 65-87 (1985)

12. C. Kreß, The Oxford Handbook of the Use of Force in International Law, (Oxford University Press, Oxford, 2015)

13. E. Henderson, Article 2(4) of the United Nations Charter: Whimsical Ideal or Binding Legal Obligation in Relation to Operation Iraqi Freedom?" (Canta LR, 2004)

14. H. C. M Charlesworth, AUYrBkIntLaw Pp. 1-31 (1984)

15. B. R. Roth, Sovereign Equality and Non-Liberal Regimes (NYIL, 2012)

16. E. Wilmshurst, Principles of International Law on the Use of Force by States In SelfDefence (Cathamhouse, 2005)

17. D. Kretzmer,EJIL 24, 1, Pp. 235-282 (2013)

18. M. E. O'Connell, The Myth of Preemptive Self-Defense (The American Society of International Law Task Force on Terrorism, 2002) 